\title{
Plasma catecholamines in Down's syndrome, at rest and during sympathetic stimulation
}

\author{
G UDESCHINI, * G CASATI, F BASSANI, GB PICOTTI, P CULOTTA \\ From the Department of Pharmacology, University of Milan, the Vimercate General Hospital, Vimercate, \\ Milan and the Piccolo Cottolengo di Don Orione, Milan, Italy
}

SUMMARY Five adult female patients with Down's syndrome were compared with five agematched controls in the standing and cold pressor tests. In both tests, there were no differences between the two groups in heart rate, systolic and diastolic blood pressure or plasma noradrenaline, adrenaline and dopamine concentrations. However, plasma adrenaline tended to be higher in the Down's group, both in the standing and the cold pressor tests.

Views differ regarding the claims that sympathetic activity is decreased in Down's syndrome, ${ }^{12}$ based on the low plasma dopamine- $\beta$-hydroxylase $(\mathrm{DBH})$ levels, ${ }^{1-4}$ and a later brief statement by one investigator that plasma noradrenaline (NA) levels are normal and that they increase normally after standing. ${ }^{5}$ The present work was aimed at assessing sympathetic activity in individual Down's patients under basal conditions and during standing and the cold pressor test. For this purpose, plasma NA and adrenaline (A) concentrations were measured as indices of neurosympathetic and adrenomedullary function. ${ }^{6}$

\section{Patients and methods}

Five adult females ranging in age between 14 and 45 years, with a mean age of 29 years, with karyotypes of Down's syndrome, were compared with five age matched normal female consenting controls. The subjects in both groups, who were taking no drugs and were not fasting, were left to lie down for $30 \mathrm{~min}$ in the supine position in a quiet room. An indwelling heparinised catheter was inserted into an antecubital vein and clotting prevented by saline drop perfusion. Basal blood pressure was recorded with a sphygmomanometer and heart rates electrocardiographically after $\mathbf{3 0} \mathrm{min}$ in the supine position. At the same time, a blood sample was drawn for plasma catecholamine determination. The subjects then assumed the orthostatic posi-

*Deceased

Address for reprint requests: Dr GB Picotti, Department of Pharmacology, University of Milan, Via Vanvitelli 32, 20129 Milan, Italy.

Received 17 July 1984 and in revised form 5 February 1985. Accepted 9 February 1985. tion, the blood pressure and heart rates were recorded 1 and 5 min afterwards and a blood sample was drawn after 5 min of standing. In the cold pressor test, blood pressures and heart rates were recorded and blood samples were $O$ drawn prior to immersion of one hand in cold water $\left(4^{\circ} \mathrm{C}\right)$ for $1 \mathrm{~min}$, at the end of the immersion and $5 \mathrm{~min}$ after- $\mathbb{D}$ wards. Dopamine (DA), NA and A were measured in $50 \mu \mathrm{l}$ plasma by a radioenzymatic method, ${ }^{7}$ as previously described. 6 Values are expressed as means \pm SE. Data 8 were analysed statistically by the paired or unpaired Student $t$ tests for comparison of two means.

\section{Results}

As shown in table 1, plasma catecholamine levels, heart rates and systolic and diastolic blood pressures did not differ between Down's patients and controls, either before or after standing. Both groups showed normal sympathetic responses to standing, with increases in plasma NA and heart rate. In the Down's group there was a tendency of plasma $A$ to increase after standing, with levels that were not, however, significantly different from the values in controls.

During the cold pressor test, there were also no differences between the Down's and the control group in the parameters studies (table 2). Increases from pre-test values were recorded in both groups for heart rates and in the control group for systolic blood pressure, after $1 \mathrm{~min}$ of the test. Both parameters were back to basal values at $5 \mathrm{~min}$. Plasma catecholamine concentrations showed inconsistent changes throughout the test in both Down's patients and controls. However, as observed throughout the 
Table 1 Plasma adrenaline (A), noradrenaline (NA) and dopamine (DA) concentrations, heart rate (HR), systolic (SBP) and diastolic (DBP) blood pressure in Down's patients and controls, in the supine position and after 5 min standing

\begin{tabular}{|c|c|c|c|c|}
\hline & \multicolumn{2}{|l|}{ Controls } & \multicolumn{2}{|l|}{ Down's } \\
\hline & Supine & Standing & Supine & Standing \\
\hline $\begin{array}{l}\text { A }(\mathrm{pg} / \mathrm{ml}) \\
\text { NA }(\mathrm{pg} / \mathrm{ml}) \\
\text { DA }(\mathrm{pg} / \mathrm{ml}) \\
\text { HR }(\mathrm{beats} / \mathrm{min}) \\
\text { SBP }(\mathrm{mm} \mathrm{Hg} \text { ) } \\
\text { DBP }(\mathrm{mm} \mathrm{Hg})\end{array}$ & $\begin{aligned} 37 & \pm 7 \\
208 & \pm 28 \\
57 & \pm 10 \\
77 & \pm 5 \\
104 & \pm 4 \\
64 & \pm 2\end{aligned}$ & $\begin{aligned} 32 & \pm 10 \\
391 & \pm 19^{*} \\
57 & \pm 12 \\
84 & \pm 4^{*} \\
106 & \pm 2 \\
67 & \pm 4\end{aligned}$ & $\begin{aligned} 43 & \pm 9 \\
223 & \pm 13 \\
29 & \pm 5 \\
84 & \pm \\
111 & \pm 5 \\
73 & \pm 3\end{aligned}$ & $\begin{aligned} 65 & \pm 14 \\
455 & \pm 49^{*} \\
35 & \pm 5 \\
98 & \pm 5^{*} \\
116 & \pm 9 \\
75 & \pm 5\end{aligned}$ \\
\hline
\end{tabular}

Figures are means \pm SE of 5 subjects. Statistical significance by paired Student $t$ test: ${ }^{*}=\mathrm{p}<0.01$ vs supine values.

Table 2 Plasma adrenaline (A), noradrenaline (NA) and dopamine (DA), heart rate (HR), systolic (SBP) and diastolic (DBP) blood pressure in Down's patients and controls before and after a cold pressor test lasting $1 \mathrm{~min}$

\begin{tabular}{|c|c|c|c|c|c|c|}
\hline & \multicolumn{3}{|l|}{ Controls } & \multicolumn{3}{|l|}{ Down's } \\
\hline & O time & $1 \mathrm{~min}$ & $5 \mathrm{~min}$ & $O$ time & $1 \mathrm{~min}$ & $5 \mathrm{~min}$ \\
\hline $\begin{array}{l}\text { A }(\mathrm{pg} / \mathrm{ml}) \\
\text { NA }(\mathrm{pg} / \mathrm{ml}) \\
\text { DA (pg/ml) } \\
\text { HR (beats/min) } \\
\text { SBP (mm Hg) } \\
\text { DBP (mm Hg) }\end{array}$ & $\begin{aligned} 37 & \pm 4 \\
213 & \pm 24 \\
53 & \pm 14 \\
76 & \pm 7 \\
113 & \pm 7 \\
71 & \pm 6\end{aligned}$ & $\begin{aligned} 50 & \pm 14 \\
259 & \pm 24 \\
67 & \pm 15 \\
96 & \pm 13^{*} \\
132 & \pm 5^{*} \\
85 & \pm 3\end{aligned}$ & $\begin{array}{r}45 \pm 11 \\
257 \pm 48 \\
53 \pm 13 \\
73 \pm 3 \\
112 \pm 6 \\
70 \pm 5\end{array}$ & $\begin{array}{r}60 \pm 16 \\
272 \pm 42 \\
36 \pm 10 \\
79 \pm 6 \\
124 \pm 5 \\
73 \pm 3\end{array}$ & $\begin{array}{r}60 \pm 25 \\
267 \pm 33 \\
34 \pm 13 \\
92 \pm 7 \dagger \\
139 \pm 6 \\
82 \pm 4\end{array}$ & $\begin{aligned} 65 & \pm 21 \\
293 & \pm 28 \\
27 & \pm 6 \\
83 & \pm 5 \\
119 & \pm 3 \\
73 & \pm 3\end{aligned}$ \\
\hline
\end{tabular}

Figures are means \pm SE of 5 subjects. Statistical significance by paired Student $t$ test: ${ }^{*}=p<0.05$ and $\dagger=p<0.01$ vs pre-test $(0$ time $)$ values.

study, plasma A tended to be higher and DA to be lower in the Down's group.

\section{Discussion}

Standing is an overall autonomic arc reflex test in which carotid sinus afferents, bulbar centres integration, sympathetic and parasympathetic efferent pathways are involved, whilst the cold pressor test is an index of orthosympathetic efferent activity. ${ }^{8}$

The present work has established that in Down's syndrome, passing from the supine to the orthostatic position causes the heart rate and the plasma NA to increase as much as in the controls. This appears to resolve the opposite views of deficient ${ }^{1-4}$ versus normal ${ }^{5}$ sympathetic activity in Down's syndrome, supporting the latter view. In the Down's group there was an exaggerated plasma $A$ response to standing. This might be accounted for by the stress to the Down's group of undergoing the test while constrained in the immobile position of the standing procedure.

In the cold pressor test too, there were no differences between Down's patients and controls in heart rate, systolic and diastolic blood pressure or plasma NA. During the cold pressor test, as with standing, the stress associated with the procedure may have been the causative factor of the high values of plasma $A$ in the Down's group.

In conclusion, the present work has established that in adult Down's patients there is normal sympathetic nervous activity, as reflected by plasma NA concentrations in peripheral blood.
Support of Italian National Research Council (CNR grant no. 80.01139.83, Progetto Finalizzato Medicina Preventiva) is gratefully acknowledged.

\section{References}

' Freedman LS, Goldstein M. Serum dopamine- $\beta$ hydroxylase activity in Down's syndrome. A familial study. Res Commun Chem Pathol Pharmacol 1974;8:543-9.

${ }^{2}$ Goldstein M, Freedman LS, Ebstein RP, Park DH. Studies on dopamine- $\beta$-hydroxylase in mental disorders. J Psychiatr Res 1974;11:205-10.

${ }^{3}$ Wetterberg L, Gustavson KH, Bäckström M, Ross SB, Fröden $O$. Low dopamine- $\beta$-hydroxylase activity in Down's syndrome. Clin Genet 1974;11:205-10.

4 Coleman M, Campbell M, Freedman LS, Roffman M, Ebstein RP, Goldstein M. Serum dopamine- $\beta$ hydroxylase levels in Down's syndrome. Clin Genet 1974;5:312-5.

${ }^{5}$ Ziegler M. Plasma levels of norepinephrine in patients with primary or secondary disturbances of the autonomic nervous system. pp. 675-678 in Kopin IJ (moderator). Plasma levels of norepinephrine. Ann Intern Med 1978;88:671-80.

- Bühler HU, Da Prada M, Haefely W, Picotti GB. Plasma adrenaline noradrenaline and dopamine in man and different animal species. $J$ Physiol (Lond) 1978;226:311-20.

${ }^{7}$ Da Prada M, Zürcher G. Simultaneous radioenzymatic determination of plasma and tissue adrenaline, noradrenaline and dopamine within the fentomole range. Life Sci 1976;19:1161-74.

8 Johnson RH, Spalding JMK. Disorders of the Autonomic Nervous System. Oxford: Blackwell Scientific Publication, $1974 ; 3: 41$. 